\title{
CORPORATE SOCIAL RESPONSIBILITY (CSR) DALAM PERSPEKTIF EKONOMI ISLAMPADA BANK SYARIAH
}

\author{
Muslihati, Siradjuddin, Syahruddin
}

UIN Alauddin Makassar || muslihatiyunding @ymail.com

\begin{abstract}
Abstrak
Penelitian ini bertujuan untuk menguraikan konsep CSR dalam perspektif ekonomi Islam dan kedudukannya pada perbankbankan syariah serta mengetahui kendala dan upaya dalam pelaksanaanya.Penelitian ini menggunakan paradigma kualitatif dengan jenis field research dengan menggunakan pendekatan teologi normatif dan sosial ekonomi.

CSR dalam ekonomi Islam aberpegang pada beberapa prinsip yaitu prinsip Tauhid, Khalifah, Keadilan, Ukhuwah dan Mewujudkan maslahah. Berangkat dari prinsip-prinsip tersebut maka kemudian muncul beberapa kriteria yang dapat dijadikan indikator bagi bank syariah dalam pelaksanaan CSR-nya. Kriteria tersebut adalah kriteria kepatuhan syariah, keadilan dan kesetaraan, bertanggung jawab dalam bekerja, jaminan kesejahteraan, jaminan kelestarian alam dan bantuan sosial.

Berdasarkan hasil analisa laporan tahunan serta laporan keberlanjutan, penulis menemukan bahwa tidak semua kriteria CSR bank syraiah diungkapkan oleh ketiga bank yang diteliti. Ada beberapa poin kriteria CSR bank syariah yang belum disajikan seperti kurangnya program yang berkaitan dengan pelestarian alam, penggunaan pendapatan non halal untuk CSR, distribusi program yang belum merata, penentuan sasaran kegiatan CSR, kurangnya kemitraan, sosialisasi kegiatan dan pemahaman mengenai pelaksanaan, evaluasi di lapangan serta keberlanjutan program. Kriteria CSR pada bank Syariah merupakan suatu tawaran kepada bank-bank syariah dalam melaksanakan program-program CSR-nya agar bersesuaian dengan prinsip-prinsip dalam ekonomi Islam.
\end{abstract}

Kata kunci: CSR, Ekonomi Islam, Bank Syariah 


\begin{abstract}
This study aims to describe the concept of CSR in the perspective of Islamic economics and its position on Islamic banking and know the constraints and efforts in the implementation. This research uses a qualitative paradigm with field research type using the normative and socio-economic theology approach.

CSR in Islamic economics aberpegang on some principles that is the principle of Tawheed, Caliph, Justice, Ukhuwah and realize maslahah. Departing from these principles then then appears some criteria that can be used as an indicator for sharia banks in the implementation of its CSR. These criteria are the criteria of Shariah compliance, justice and equality, responsible for work, welfare, sustainability and social assistance.

Based on the results of annual report analysis and sustainability report, the authors found that not all CSR bank syraiah criteria were disclosed by the three banks studied. There are several criteria of CSR syariah banks that have not been presented such as lack of programs related to nature conservation, non-halal income usage for CSR, uneven distribution of programs, targeting of CSR activities, lack of partnerships, socialization of activities and understanding of implementation, on-site evaluation as well as program sustainability. The CSR criteria on Sharia banks is an offer to sharia banks in implementing their CSR programs to conform to principles in Islamic economics.
\end{abstract}

Keywords: CSR, Syariah Banking, Islamic Economics.

\section{PENDAHULUAN}

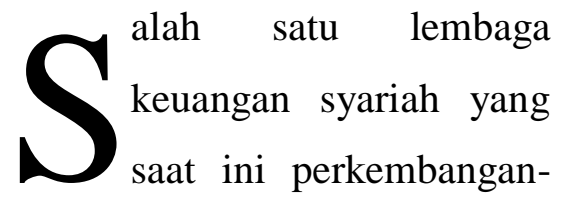

nya begitu pesat adalah sektor bank

umum maupun bank pembiayaan

syariah. Bank secara operasional dibina

dan diawasi oleh Bank Indonesia

sebagai bank sentral di Indonesia.

Sedangkan pembinaan dan pengawasan

dari sisi pemenuhan prinsip-prinsip

syariah dilakukan oleh Dewan Syariah

Nasional MUI.

Secara operasional, model harus berpijak pada masalah sosial dan

bisnis bank syariah mencakup aspek lingkungan. Karena kondisi keuangan bisnis dan non bisnis (seperti aspek syariah/sosial) dari beragam aktivitas ekonomi dan sosial masyarakat.

Salah satu program yang dilakukan oleh suatu perusahaan yang kini juga diterapkan pada perbankan syariah adalah tanggung jawab sosial perusahaan atau coorporate social responsibility (selanjutnya disebut CSR). CSR merupakan bagian dari aspek sosial dari operasional bank syariah.

Tanggung jawab perusahaan

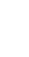

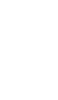


saja tidak cukup menjamin nilai ajaran Islam itu sendiri. Tujuan dari perusahaan tumbuh secara ber- syariat Islam (Maqasid al-syari'ah) kelanjutan (Ali, 2015:1). Keberlanjutan adalah maslahah sehingga bisnis perusahaan hanya akan terjamin adalah upaya untuk menciptakan apabila perusahaan memperhatikan maslahah, bukan sekedar mencari dimensi sosial dan lingkungan hidup. keuntungan (Hendri dan Retno,

Di Indonesia, Pemerintah secara 2008:20). Bisnis dalam Islam memiliki khusus mendorong peran serta posisi yang sangat mulia sekaligus perusahaan perusahaan untuk melakukan kegiatan CSR. Regulasi mengenai hal tersebut tertuang dalam pasal 74 Undang-Undang Nomor 40 Tahun 2007 tentang Perseroan Terbatas. Aturan lain yang juga memuat mengenai CSR adalah Undang-Undang No. 25 Tahun 2007 Pasal 15(b) dan Pasal 16 (d) tentang Penanaman Modal. Hal yang sama juga berlaku bagi entitas lemgbaga keuangan syariah dalam hal ini perbankan syariah dalam melaksanakan aktivitas CSR-nya.

Keberhasilan sebuah korporat tidak hanya ditentukan dari keberhasilan bisnisnya, namun kemampuan menyukseskan program pemberdayaan masyarakat juga turut berperan karena kepedulian korporat terhadap lingkungan sekitar mampu menghasilkan kinerja bisnis yang baik.

CSR dalam perspektif Islam merupakan konsekuensi inhern dari strategis karena bukan sekedar diperbolehkan di dalam Islam, melainkan justru diperintahkan oleh Allah dalam al-Qur'an (Ali, 2015:3). Sebagaimana dijelaskan dalam QS alJumu'ah/62:10

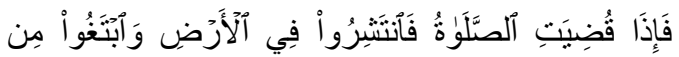

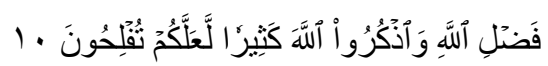
Terjemahnya: apabila telah ditunaikan shalat, Maka bertebaranlah kamu di muka bumi; dan carilah karunia Allah dan ingatlah Allah banyak-banyak supaya kamu beruntung.

CSR selaras dengan pandangan Islam tentang manusia sehubungan dengan dirinya sendiri dan lingkungan sosial, dapat dipresentasikan dengan empat aksioma yaitu kesatuan (tauhid), keseimbangan (equilibrum), kehendak bebas (free will) dan tanggung jawab (responsibility)(Darmawati, 2014:134). 
Aktivitas CSR di perbankan 2001:4). Sebagaimana yang akan syariah pada dasarnya telah melekat diteliti secara lebih lanjut pada sesuai secara inhern sebagai konsekuensi dengan latar belakang diatas.

kebersandaran bank syariah pada ajaran METODE PENELITIAN

Islam. Berbeda dengan bank Penelitian ini merupakan konvensional tidak dapat dipisahkan penelitian kualitatif. Penelitian secara dikotomis antara orientasi bisnis kualitatif adalah salah satu metode dengan orientasi sosialnya. Orientasi penelitian yang bertujuan untuk bisnis seharusnya juga membawa mendapatkan pemahaman tentang orientasi sosial, atau setidaknya tidak kenyataan melalui proses berpikir kontradiksi dengan orientasi sosial induktif. Melalui penelitian kualitatif (Hendri dan Retno, 2008:20). Hal ini peneliti dapat mengenali subjek, membawa konsekuensi pada kuatnya karakter sosial dari perbankan syariah dalam melaksanakan aktivitas-aktivitas sosialnya, relatif jika dibandingkan dengan bank konvensional.

Bank umum syariah di Indonesia terutama yang telah memiliki cakupan bisnis yang luas, telah menerapkan program CSR dalam operasionalnya. Sebagai institusi yang berpedoman pada ketentuan syar'i dalam melakukan aktivitias bisnisnya, bank umum syariah dituntut untuk memiliki kepedulian yang besar terhadap masyarakat sekitar sekaligus menyadari bahwa hubungan baik yang dibangun bersama masyarakat juga merupakan salah satu faktor penentu dalam pencapaian bisnis (Antonio, merasakan apa yang mereka alami dalam kehidupan sehari-hari (Basrowi, 2008:2). Sedangkan jenis penelitian ini adalah penelitian lapangan (field research), meskipun dalam penelitian ini, peneliti tidak secara langsung terjun ke lapangan untuk meneliti tentang kegiatan CSR pada perbankan syariah melainkan menjadikan laporan tahunan dan laporan keberlanjutan sebagai objek penelitan, akan tetapi data-data yang digunakan adalah data yang merupakan hasil dari penelusuran situasi dan kondisi di lapangan.

Adapun pendekatan yang digunakan yang pertama adalah pendekatan Teologi Normatif yaitu dimaksudkan untuk mendapatkan landasan dan konsep dasar dalam 
agama karena hendak mengkaji konsep CSR dalam perspektif Ekonomi Islam. Selain itu Pendekatan Sosial Ekonomi juga digunakan karena pendekatan ini digunakan untuk mengetahui kondisi sosial masyarakat, baik yang terkait dengan perbuatan hukum, konsepsi, nilai, dan kebiasaan masyarakat khususnya dalam penelitian ini dalam aspek ekonomi.

Data sekunder dalam penelitian ini adalah laporan tahunan dan laporan keberlanjutan dari tiga bank syariah yaitu, Bank Syariah Mandiri, Bank Muamalat Indonesia dan Bank BNI Syariah serta diperoleh pula dari mengumpulkan, membaca, dan memahamibuku-buku dan jurnal yang yang berkaitan dengan riset ini. Peneliti melakukan identifikasi wacana dari sumber data penelitian yang berkaitan dengan kajian tentang CSR untuk kemudian mengumpulkan data yang relevan dengan penelitian untuk kemudian diolah dan di analisis.

Dalam penelitian kualitatif, yang menjadi instrumen atau alat penelitian adalah peneliti itu sendiri sehingga peneliti harus "divalidasi". Validasi terhadap peneliti, meliputi; pemahaman metode penelitian kualitatif, penguasaan wawasan terhadap bidang yang diteliti, kesiapan peneliti untuk memasuki objek penelitian -baik secara akademik maupun logiknya. (Hermansyah, 2009:306)

Analisis data dalam penelitian kualitatif, dilakukan pada saat pengumpulan data berlangsung, dan setelah selesai pengumpulan data dalam periode tertentu (Sugiyono). Aktifitas dalam analisis data yaitu dengan mereduksi data, mendisplaykan data, maka akan memudahkan untuk memahami apa yang telah terjadi, merencanakan kerja selanjutnya berdasarkan apa yang telah dipahami tersebut. Untuk kemudian dilakukan penarikan kesimpulan

Untuk menguji kredibilitas data penelitian, peneliti menggunakan teknik Triangulasi. (Nusa Putra dan Ninin Dwi Lestari, 2012:87) Teknik triangulasi data adalah menjaring data dengan berbagai metode dan cara dengan menyilangkan informasi yang diperoleh agar data yang didapatkan lebih lengkap dan sesuai dengan yang diharapkan. Setelah mendapatkan data yang jenuh yaitu keterangan yang 
didapat dari sumber-sumber data telah sama maka data yang didapatka lebih kredibel.

\section{HASIL PENELITIAN PEMBAHASAN}

Dalam melihat realisasi CSR yang sesuai dengan prinsip ekonomi Islam digunakan kriteria -kriteria yang memuat beberapa poin indikator CSR pada bank syariah, adapun kriteria tersebut adalah sebagai berikut:

a. Kriteria Kepatuhan Syariah

b. Kriteria Keadilan dan Kesetaraan

c. Kriteria bertanggung jawab dalam bekerja

d. Kriteria Jaminan Kesejahteraan

e. Kriteria Jaminan Kelestarian Alam

f. Kriteria Bantuan Sosial Berdasarkan data statistik yang dirilis oleh OJK per Desember 2017 tercatat di Indonesia terdapat 13 Bank Umum Syariah dan 21 Unit Usaha Syariah yang tersebar di seluruh Indonesia. Jika dilihat dari jumlah jaringan kantor individual yang dimiliki maka tiga bank yang termasuk adalah, Bank Syariah Mandiri, Bank Muamalat, dan BNI Syariah.Bank dengan market share yang luas seperti beberapa bank diatas sudah sepatutnya melaksanakan

CSR dalam operasionalnya. Hal tersebut dapat diketahui dari laporan tahunan dan laporan keberlanjutan dari masingmasing bank syariah tersebut. Program dari tiap-tiap bank akan berbeda tapi pada dasarnya memiliki tujuan yang sama.

\section{Bank Syariah Mandiri (BSM)}

BSM menguraikan kegiatan

CSR dalam laporan tahunannya sebanyak dua belas halaman cukup sedikit jika dilihat dari total halaman laporan tahunan secara keseluruhan yakni 416 halaman.

Pelaksanaan program CSR di BSM memiliki 2 (dua) sumber dana,yakni Dana Zakat Infak Shadaqah (ZIS) dan Dana Kebajikan. Dana zakat diperoleh dari zakat perusahaan (BSM), Zakat dari nasabah atau umum, dan zakat pegawai BSM. Pada tahun 2016 total dana zakat BSM mencapai 22 Miliar sedangkan dana kebajikan dana kebajikan bersumber dari denda, pendapatan non halal dan dana sosial lainnya.

BSM dalam menjalankan kegiatan bisnis maupun sosialnya mengutamakan aspek kepatuhan syariahnya baik dari segi instrumen bank serta produk simpanan maupun 
pembiayaan. Hal tersebut kemudian dipertegas oleh Laporan Dewan Pengawas Syariah bagian opini Dewan Pengawas Syariah.

Dari segi aspek keadilan dan kesetaraan, serta bertanggung jawab dalam bekerja, secara umum telah dipenuhi oleh BSM, hal tersebut dapat dilihat dari uraian Tata Nilai Perusahaan yang disebut dengan Ethic pada Laporan Keberlanjutan BSM tahun 2016.

Kriteria Jaminan kesejahteraan pada poin tempat bekerja yang aman telah dilaksanakan BSM yang diketahui melalui laporan tahunannya:

"Bank terus berupaya menciptakan suasana kerja yang nyaman bagi setiap pegawai BSM, dengan melengkapi sarana dan prasarana penunjang pekerjaan. Kelengkapan sarana dan prasarana tersebut untuk memastikan terjaminnya kebutuhan dan operasional perusahaan dan terjaminnya keselamatan kerja bagi pegawai." (Laporan Tahunan 2016 halaman 77)

Dalam hal kontribusinya terhadap keletarian alam BSM telah melakukan beberapa kegiatan yang tujuannya untuk kebaikan lingkungan seperti penghijauan, bantuan bencana alam, pembagian bibit tanaman. Selain itu lebih detail dijelaskan pada laporan keberlanjutan BSM tahun 2016 melalui ikhtisar Kinerja Lingkungan yaitu bantuan sanitasi dan perbaikan saluran air bersih yang tersebar di seluruh indonesia dengan dana mencapai Rp1,96 miliar. Program BSM Green Office melalui kebijakan perusahaan untuk menerapkan berbagai penghematan.

Aspek bantuan kebijakan secara jelas telah dijelaskan pula oleh BSM dalam laporan keberlanjutannya pada bagian Ikhtisar Kinerja Sosial dimana BSM bekerja sama dengan LAZNAS BSM melalui "Program Didik Umat" berupa pemberian bantuan pendidikan danbeasiswa dengan dana mencapai Rp2,36 miliar. Program Simpati Umat" berupa pemberian bantuan perbaikan sarana prasarana, bantuan kesehatan, bantuan bencana alam dan sebagainya di seluruh Indonesia dengan dana mencapai Rp3,20 miliar.

Secara keseluruhan BSM telah melaksanakan keseluruhan kriteria yang ada hanya saja pada poin menghindari keuntungan yang didapat tidak secara halal masih menjadi pertimbangan dikarenkan BSM tidak 
dapat menghindari adanya pendapatan tersebut.

\section{Bank Muamalat Indonesia}

BMI dalam laporan tahunannya yang diuraikan sebanyak 464 halaman lebih banyak dibandingkan dengan BSM dan uraian tentang kegiatan CSR sebanyak 38 halaman. Dalam pelaksanaan aktivitas CSR Bank Muamalat terdapat beberapa sumber pendanaan, di antaranya berasal dari dana perusahaan, dana zakat karyawan dan perusahaan, serta dana lainnya seperti sumber lainnya yang halal (infaq dan shadaqoh) dan sumber lainnya yang tidak dapat diakui sebagai pendapatan bank.

Berdasarkan rincian dana kegiatan CSR dapat diketahui bahwa penyaluran dana CSR BMI tahun 2016 adalah dari dana zakat karyawan atau perusahaan sebesar Rp.1,66 Miliar, dana infaq sebesar Rp. 386. 615.500, dana non ZIS Rp. 261.347.600 dan dana perusahaan sebesar Rp. 58.729.100, total keseluruhan dana yaitu Rp. 2.373.603.940.

Adapun uraian kegiatan CSR BMI berdasarkan kriteria CSR pada bank syariah pertama dapat dilihat dari kriteria kepatuhan syariah yang dapat dilihat melalui keberadaan pernyataan Dewan Pengawas Syariah (DPS). Laporan Dewan Pengawas Syariah dalam hal ini memberikan jaminan bahwa operasional dan produk bank syariah telah sesuai dengan fatwa Dewan Syariah Nasional (DSN), Majelis Ulama Indonesia, dan Opini DPS.

Aspek bertanggung jawab dalam bekerja dari BMI dapat dilihat dari dibuatnya nilai-nilai muamalat yang diterapkan oleh BMI sebagaimana dijelaskan dalam laporan tahunanya pada bagian nilai-nilai muamalat.

Aspek keadilan dan kesetaraan juga memjadi dasar yang penting yang diungkapkan BMI dalam laporan tahunannya pada bagian Implementasi Tata kelola perusahaan:

"Bank Muamalat Indonesia dan segenap Jajaran Bank Muamalat Indonesia bertindak dengan memperhatikan prinsip-prinsip keadilan dan kesetaraan bagi semua pihak yang meliputi tetapi tidak terbatas pada Bank Muamalat Indonesia menerapkan prinsip kewajaran yang diimplementasikan sebagai keadilan dan kesetaraan (equal treatment) di dalam memenuhi hak-hak 
Stakeholders yang timbul berdasarkan perjanjian dan peraturan perundangundangan yang berlaku." (Laporan Tahunan 2016 halaman 213-214)

Kriteria jaminan kesejahteraan pada dasarnya lebih berfokus pada hakhak para pegawai. Wujud dari pemenuhan kriteria jaminan kesejahteraan oleh BMI dapat dilihat dari pelaksanakan Kategori Program Learning yang secara rinci dijelaskan pada laporan tahunan BSM 2016 bagian Tinjauan Operasional.

Kritera jaminan kelestarian alam oleh BMI kemudian diwujudkan salah satunya melalui program kegiatan green campaign yang ditujukan untuk karyawan internal Bank Muamalat, dengan tujuan peningkatan awareness karyawan tentang pentingnya membuat perubahan dan memberikan kontribusi positif untuk lingkungan sekitar dimana mereka menjalankan operasional kegiatan kantor sehari-hari, khususnya keseimbangan antara operasional perusahaan dengan keberlangsungan lingkungan hidup.

Aspek terakhir yang paling mudah di identifikasi sebagai bagian dari kegiatan CSR BMI adalah kriteria bantuan kebajikan. Pemenuhan kriteria ini dapat diketahui dari tanggung jawab BMI terhadap pengembangan sosial kemasyarakatan diwujudkan dalam berbagi bidang seperti Program Green Horti Cianjur yaitu program usaha tani berbasis community farming yang secara substansial berusaha mengatasi permasalahan usaha tani dengan pendekatan agrobisnis. Pemberian beasiswa dan bantuan kepada beberapa sekolah kaitanya dalam hal pendidikan serta bantuan kemanusiaan seperti pelaksanaan donor darah, qurban, bantuan atas bencana alam dan perbaikan terhadap infrastruktur yang digunakan masyarakat umum. Hal ini sesuai dengan beberapa poin dalam kriteria CSR dalam hal bantuan kebijakan.

Peneliti tidak menemukan laporan keberlanjutan dari BMI pada website resminya berbeda dengan BSM yang menyajikan laporan keberlanjutannya pada website resminya dan dengan mudah untuk diakses. Hal ini akan mempengaruhi persepsi masyrakat terhadap keterbukaan informasi yang diberikan oleh BMI.

\section{BNI Syariah}


Laporan Tahunan 2016 BNI Hasanah. BNI Syariah juga Syariah diuraikan sebanyak 446 memadukan maqoshid syariah dengan halaman, bagian yang menjelaskan Anggaran Dasar Perusahaan yang tentang kegiatan CSRnya diuraikan terwujud dalam kegiatan operasionalsebanyak 40 halaman. Selain itu nya. Dibandingkan dua bank kegiatan CSR BNI Syariah dapat sebelumnya, BNI Syariah sedikit lebih diketahui melalui laporan keberlanjutan BNI Syariah tahun 2016 sebnyak 158 halaman.

Dana pelaksanaan program CSR BNI Syariah berasal dari zakat Perusahaan, zakat pegawai dan zakat pihak lainnya yang dikelola oleh Yayasan Hasanah Titik. Pada tahun 2016, jumlah zakat Perusahaan mencapai Rp8,41 miliar, sedangkan zakat pegawai mencapai Rp8,04 miliar, sehingga secara keseluruhan dana dana zakat yang dikelola oleh Yayasan Hasanah Titik mencapai Rp16,45 miliar

Kriteria pertama dalam mendetail dalam memaparkan prinsip syariah dalam kegiatan usaha dan operasionalnya. Baik pada laporan tahunan maupun pada laporan keberlanjutannya.

Pada kriteria keadilan dan kesetaraan BNI Syariah mencantumkannya dalam kode etik yang juga di uraikan dengan lengkap pada laporan keberlanjutannya pada bagian strukur tata kelola.

Kriteria bertanggung jawab dalam bekerja sebagaimana pada kriteria sebelumnya, juga dimuat dalam tata nilai serta kode etik perusahaan.

$\begin{array}{rllr}\text { Kriteria pertama dalam } & \text { Kemudian pada kriteria jaminan } \\ \text { pelaksanaan CSR di perbankan syariah } & \text { kesejahteraan pada poin tentang tempat } \\ \text { adalah kepatuhan syariah. BNI syariah } & \text { bekerja yang aman dapat diketahui } \\ \text { menjadikan kepatuhan syariah sebagai } & \text { melalui uraian pada } & \text { laporan } \\ \text { sebagai pertimbangan utama dalam } & \text { keberlanjutan } & \text { bagian } & \text { aspek } \\ \text { menjalanka kegiatan usaha dan } & \text { kepegawaian. Masih dalam kriteria } \\ \text { operasionalnya selain dari hukum serta } & \text { yang sama pada poin upah yang sesuai } \\ \text { regulasi yang berlaku di Indonesia. } & \text { juga dapat dilihat pada bagian aspek } \\ \text { BNI Syariah memiliki tata nilai } & \text { kepegawaian tersebut. }\end{array}$
meliputi Amanah dan Jama'ah serta 
Sepanjang tahun 2016, BNI Syariah melakukan kegiatan yang berkaitan dengan kepedulian lingkungan hidup, sebagai berikut:

a. Penanaman 1000 pohon di lingkungan yang berada di daerah terpencil di Dusun Parung Ponteng Desa Tajur Kec. Citeureup Kab. Bogor.

b. Menghemat Kertas, Air, Listrik

c. Mengelola Limbah

d. Rutin Uji Emisi Kendaraan Operasional

Pemenuhan kriteria yang terakhir adalah bantuan kebajikan sebagaimana yang dijelaskan oleh BNI Syariah dalam laporan keberlanjutannya pada halaman 145-155 sebagai berikut:

Bidang ProgramPendidikan
a. Beasiswa Pegawai Dasar
b. Taman Pustaka Hasanah
c. Upgrading Guru Madrasah
d. Mobil Cerdas Hasanah

Kesehatan dan Lingkungan

a. Kampung Sehat

b. Hasanah Care Mobile (Perilaku Hidup Bersih dan Sehat PHBS+ Layanan Kesehatan Umum+ Gigi+mCK)

Sosial , Ekonomi dan Dakwah

a. ODOLOF (One Day One Liter One Family)

b. Santunan yatim/Tidak mampu

c. Tadarus Anak Hasanah

d. Layanan Pengurusan Jenazah e. Hasanah for Society

f. Qurban Party Hasanah

g. Jurnalis Keuangan Syariah

h. Santri Hasanah (Islamic Entrepreneurship) dan Duta Hasanah Pada kriteria jaminan kesejahteraan dari kegiatan CSR BNI Syariah dapat dilihat dari BNI Syariah juga senantiasa memastikan terciptanya wahana kerja yang kondusif. Dalam mengelola sumber daya manusianya, BNI Syariah berpegang pada prinsipprinsip persamaan dan kesetaraan dalam kesempatan kerja, kebebasan berserikat dan perlindungan kesehatan dan keselamatan kerja seluruh karyawannya.

Dalam mengelola segala kegiatan sosialnya, BNI Syariah memiliki yayasan tersendiri yang diberi nama Yayasan Hasanah Titik. Yayasan Hasanah Titik adalah lembaga sosial, kemanusiaan dan keagamaan yang mempunyai afiliasi dengan pengelolaan zakat, infaq dan shadaqoh BNI Syariah. Yayasan berdiri pada Mei 2014.

\section{Kendala dan upaya dalam penerapan CSR yang berdasarkan perspektif Islam}

Penerapan CSR pada bank syariah buka terjadi tanpa kendalakendala tertentu di lapangan. Jika 
dilihat dari laporan tahunan masing- jumlah cabang dari bank tersebut masing bank syariah dalam penelitian banyak berdiri, sehingga wilayah ini terlihat masih kurangnya program- dengan jumlah cabang bank syariah program CSR yang berkaitan dengan masih sedikit bahkan belum terdapat pelestarian lingkungan, ini disebabkan oleh orientasi bisnis bank syariah yang tidak berkaitan langsung dengan isu-isu pelestarian lingkungan.

Kendala lain yang masih
k ditemukan di lapangan dalam

Tidak semua informasiinformasi terkait dengan CSR yang diungkapkan oleh bank syariah sesuai dengan konsep, kriteria serta poin CSR dalam pandangan ekonomi Islam. Ada beberapa item dalam kriteria CSR yang belum dilaksanakan secara maksimal oleh bank syariah, sepeti menghindari keuntungan yang didapat tidak secara halal pada kriteria kepatuhan syariah. Sebagaimana kita ketahui bahwa dalam bank syariah terdapat istilah pendapatan non halal yang diperoleh dari transaksi-traksaksi dengan bank konvensional. Dana tersebut oleh beberapa bank syariah digunakan dalam kegiatan CSR bank syariah. Kendala yang lain adalah distribusi kegiatan CSR yang belum merata, kegiatan-kegiatan CSR dengan skala besar masih lebih berpusat di beberapa kota besar saja yang pada dasarnya merupakan wilayah dimana bank syariah kurang dan tidak tersentu oleh program CSR dari bank syariah tersebut. pelaksanaan CSR adalah masalah biaya, distribusi kegiatan serta penetuan target, kurangnya kemitraan, sosialisasi kegiatan dan pemahaman mengenai pelaksanaan dan evaluasi di lapangan serta pentingnya bagi bankbank syariah untuk mengevaluasi pelaksanaan CSRnya agar lebih disesuaikan dengan prinsip-prinsip ekonomi Islam sebagaiman yang telah dibahas sebelumnya. Selain itu keberlanjutan dari kegiatan-kegiatan CSR tersebut juga menjadi perhatian penting agar efek jangka panjang dari kegiatan CSR tersebut dapat dirasaka.

Berangkat dari kendala-kendala yang ada maka salah satu solusi yang bisa dilakukan oleh bank syariah adalah mengevaluasi secara keseluruhan mengenai pelaksanaan kegiatan CSR dari bank syariah tersebut dengan berkaca pada beberapa pendekatan yang ada termasuk dengan mempertimbangkan rumusan kriteria- 
kriteria CSR pada Bank Syariah sebagai indikator dalam melaksanakan CSR.

\section{KESIMPULAN}

Ketiga bank yang diteliti dalam penelitian ini menyajikan tanggung jawab sosial perusahaannya dalam laporan tahunan mereka, tidak disajikan dalam laporan terpisah. Tidak semua kriteria CSR bank syraiah diungkapkan oleh ketiga bank tersebut. Ada beberapa poin kriteria CSR bank syariah yang belum disajikan.

Jika ditinjau dari banyaknya halaman, Bank Syariah Mandiri menyajikan laporan CSR sebanyak 12 halaman lebih sedikit dibandingkan dengan jumlah halaman laporan tahunan dari Bank Muamalat Indonesia yang mencapai 38 halaman. Sedangkan BNI Syariah melampaui dari kedua bank sebelumnya dengan menyajikan laporan CSR-nya sebanyak 40 halaman. Hal ini mengindikasi bahwa bank Muamalat dan BNI Syariah lebih mendetail dalam penyajian laporan CSRnya dibandingkan dengan Bank Syariah Mandiri.

Dana yang digunakan ketiga bank dalam melaksanakan kegiatan CSRnya bersumber dari dana perusahaan, dana zakat karyawan \& perusahaan, serta dana lainnya seperti sumber lainnya yang halal (infaq dan shadaqoh) dan sumber lainnya yang tidak dapat diakui sebagai pendapatan bank termasuk pendapatan yang di istilahkan dengan pendapatan non halal.
Dari segi program CSR yang dilaksanakan, program CSR dari Bank BNI Syariah lebih variatif dibandingkan dengan kedua bank yang lain, hal ini dikarenakan bank BNI Syariah telah memiliki yayasan yang didirikan untuk mengelola dana untuk kegiatan sosial perusahaan. Sedangkan Bank Syariah Mandiri dalam hal penyaluran dana CSRnya bekerja sama dengan Lembaga Amil Zakat Nasional. Jika ditinjau kembali dari kriteria CSR pada bank Syariah, ditemukan bahwa belum semua kriteria tersebut dipenuhi oleh Bank-Bank Syariah tersebut.

Adapun kendala yang dihadapi dalam usaha untuk mewujudkan pelaksanaan CSR yang sesuai degan ekonomi Islam adalah jika dilihat dari kriteria CSR bank syariah maka masih terdapat beberapa poin dari riteria tersebut yang belum dipenuhi seperti kurangnya program yang berkaitan dengan pelestarian alam, penggunaan pendapatan non halal dari bank untuk CSR, distribusi program yang belum merata, penetuan target dan sasaran kegiatan CSR, kurangnya kemitraan, sosialisasi kegiatan dan pemahaman mengenai pelaksanaan dan evaluasi di lapangan. Hal ini menunjukkan bahwa bank syariah perlu untuk mengkaji ulang konsep pelaksanaan CSRnya.

Bank syariah sepatutnya mengevaluasi pelaksanaan kegiatan CSR dari bank syariah tersebut dengan berkaca pada beberapa pendekatan yang ada termasuk dengan mempertimbangkan rumusan kriteriakriteria CSR pada Bank Syariah 
sebagai indikator dalam melaksanakan

CSR. Kriteria tersebut merupakan

suatu tawaran kepada bank-bank syariah dalam melaksanakan program CSR-nya agar bersesuaian dengan prinsip-prinsip dalam ekonomi Islam.

\section{DAFTAR PUSTAKA}

Antonio, Muhammad Syafi'I. Bank Syariah dari Teori ke Praktek. Jakarta : Gema Insani,2001.

Antonio,Muhammad Syafi'I. Bank Syariah bagi Bankir dan Praktisi Keuangan. Jakarta: Central Bank of Indonesia and Tazkia Institute, 1999.

Azheri, Busyra. Corporate Social Responsibility dari Voluntary menjadi Mandatory. Jakarta: PT.Raja Grafindo Persada, 2012.

Azheri, Isa Wahyudi dan Busyra. Corporate Social Responsibility, Prinsip,Pengaturan dan Implementasi. Malang: Intrans Publishing.2008.

Basrowi dan Suwandi. Mamahami Penelitian Kualitatif . Jakarta: Rineka Cipta, 2008.

Bank Indonesia (BI), Model Bisnis Perbankan Syariah [Online], http://www.bi.go.id, diakses September 2017.

Badroen, Faisal. Etika Bisnis dalam Islam. Jakarta: Kencana, 2006.

Bank BNI Syariah, Laporan Tahunan [Online], http://www.bnisyariah.co.id., diakses Februari 2018.

Bank Syariah Mandiri, Laporan Tahunan [Online], https://www.syariahmandiri.co.id., diakses Februari 2018.

Bank Muamalat Indonesia, Laporan Tahunan [Online], http://www.bankmuamalat.co.id., diakses Februari 2018.

Darmawati. "Corporate Social Responsibility dalam Islam.” Mazahib, vol. XIII, No. 2. (2014)

Eklington, Cannibals with Forks, the Triple Bottom Line of 21th Century. 1997.

Kartini, Dwi. Corporate Social Responsibility (Transformasi Konsep Sustainability Management dan Implementasi di Indonesia ). Bandung: PT. Refika Aditama, 2013.

Mahmud, Metode Penelitian Pendidikan. Bandung: Pustaka Setia, 2011.

Muhammad, Jawed Akhtar, "Corporate Social Responsibility in Islam". Thesis PhD Faculty of Business of New Zealand, 2007.

Otoritas Jasa Keuangan (OJK), Bank Syariah [Online], http://www.ojk.go.id/id/kanal/syariah/tentang-syariah/pages/PBS-danKelembagaan.aspx., diakses 25 Februari 2018.

Sugiyono. Metode Penelitian Bisnis. Bandung: Alvabeta, 2013.

Syukron, Ali. "CSR dalam Perspektif Islam dan Perbankan Syariah." Economic: Jurnal Ekonomi dan Hukum Islam, vol. 5, No. 1 (2015)

Wahyudi, Isa dan Busyra Azheri. Corporate Social Responsibility, Prinsip,Pengaturan dan Implementasi. Malang: Intrans Publishing, 2008. 